\title{
Purple, stiff lesions resembling varicose veins on lower limb: certainly consider Kaposi sarcoma
}

\author{
Faruk Cingoz ${ }^{1}$, Gokhan Arslan ${ }^{1}$, Ali Fuat Cicek ${ }^{2}$, Bilgehan Savas $\mathrm{Oz}^{1}$ \\ ${ }^{1}$ Department of Cardiovascular Surgery, Gülhane Military Medical Academy, Etlik, Ankara, Turkey \\ ${ }^{2}$ Department of Pathology, Gülhane Military Medical Academy, Etlik, Ankara, Turkey
}

Kardiochirurgia i Torakochirurgia Polska 2016; 13 (4): 380-382

\begin{abstract}
Kaposi's sarcoma (KS) typically presents multiple cutaneous lesions of the lower extremities. Lesions can rarely mimic varicose veins without venous insufficiency, vascular or stasis ulcers. As the initial diagnosis of KS is generally determined clinically, a high index of suspicion and palpation of lesions are necessary for all patients with atypical presentations of varicose-like lesions of lower extremities. Tissue biopsy with histological analysis is essential for all uncertain lesions. This is a case of KS occurring in a 79-year-old man who presented with indurated vascular plaques resembling varicose veins on the right foot.
\end{abstract}

Key words: cutaneous lesion, Kaposi's sarcoma, varicose vein.

\section{Introduction}

Kaposi's sarcoma (KS) is a low-grade vascular tumor that was first described by Moritz more than a century ago [1]. This vascular neoplasm has since received much attention in the literature, especially after recognition of its association with the acquired immune deficiency syndrome (AIDS) in the early 1980s. Kaposi's sarcoma lesions predominantly present at mucocutaneous sites, but may involve all organs and anatomic locations, developing in 1 of 4 different epidemiologic-clinical settings [2]. In recent years there have been several changes including its evolving epidemiology, pathogenesis, new clinical presentations and descriptions of new histologic variants [3]. Hence, it is essential that vascular surgeons must be doubtful of the atypical varicose lesions and their contemporary manifestations.

\section{Case report}

A 79-year-old man in good health presented with a 1-year history of a few raised lesions over the dorsum of the right foot extending from the level of the distal tibia. Previously, he was a diagnosed with varicose veins in the right lower extremity with inspection for which he was ad-

\section{Streszczenie}

Mięsak Kaposiego (MK) zazwyczaj objawia się licznymi zmianami skórnymi kończyn dolnych. W rzadkich przypadkach zmiany te mogą przypominać żylaki bez niewydolności żylnej albo wrzody naczyniowe lub zastoinowe. Ponieważ MK zwykle rozpoznawany jest po raz pierwszy w warunkach klinicznych, wszelkie nietypowe żylakopodobne zmiany kończyn dolnych u pacjentów należy traktować z dużą podejrzliwością i poddać palpacji. W przypadku wątpliwości co do charakteru zmian konieczne jest wykonanie biopsji tkankowej i analizy histologicznej. W niniejszej pracy przedstawiono przypadek MK u 79-letniego mężczyzny ze stwardniałymi zmianami przypominającymi żylaki na prawej stopie.

Słowa kluczowe: zmiana skórna, mięsak Kaposiego, żylak.

vised calcium dobesilate for 3 months, leg elevation and compression therapy; nevertheless, these cutaneous darkpurplish macules noted on physical examination began within the previous 6 months with recent slow progression. He was admitted to hospital again. On examination, there were some irregularly shaped, raised, diffuse, differentsized, dark-purplish macules as well as stiff and compressible lesions in palpation, over the dorsum of the right foot (Fig. 1). There was no ulcer, local tenderness or palpable thrill. The peripheral pulsations were felt. The saphenofemoral junction was competent on the Brodie-Trendelenburg test. Examination of the right leg revealed no abnormality and venous Doppler analysis of the vessels of the right extremity showed normal venous flow and patent venous valves with no signs of venous insufficiency or deep venous thrombosis. Hematological and biochemical investigations were normal. Serological testing for HIV was negative. A punch biopsy was taken from the edge of a lesion on the right foot. Pathological examination showed a nodular tumor in the subepidermal area. The tumor consisted of neoplastic cells having spindle shape nuclei, mild mitotic activity and cytological atypia consisting of vascular spaces including erythrocytes in their lumens. Immunohistochemi- 

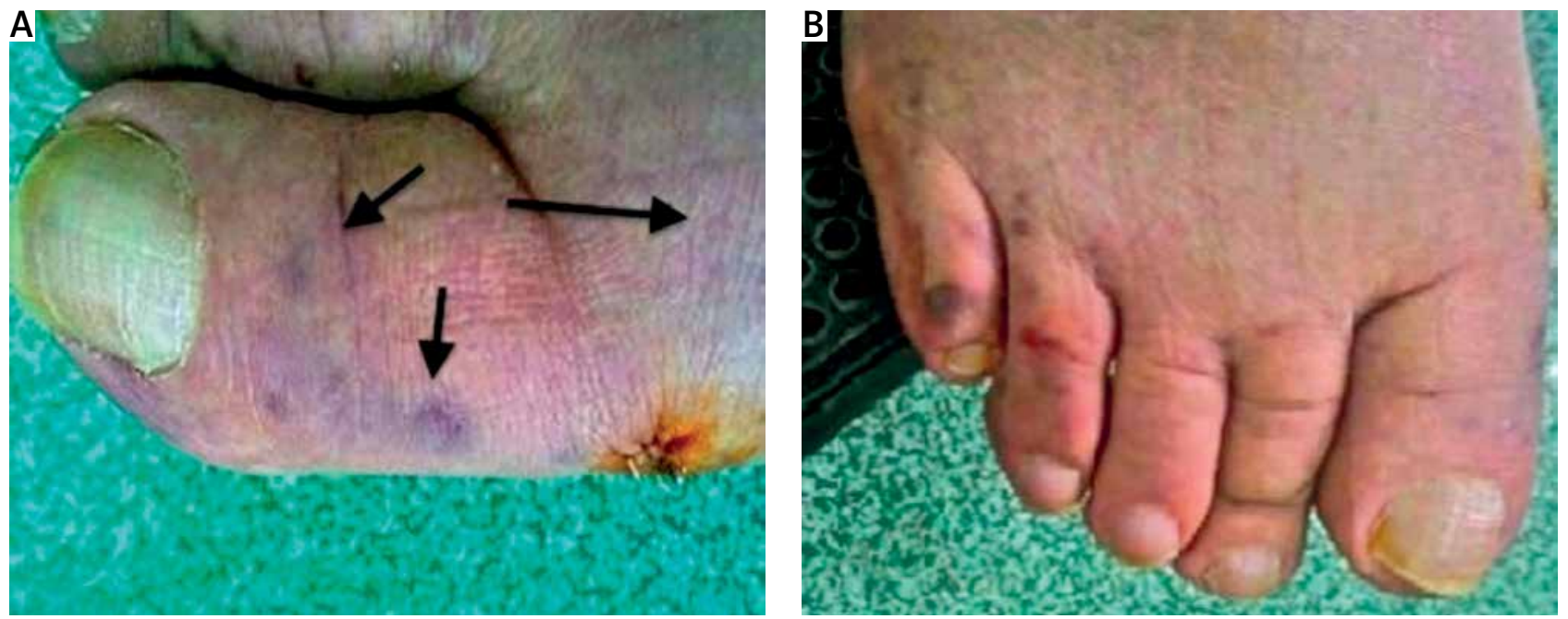

Fig. 1. Clinical photographs showing purplish skin lesions, extending from the level of the toes to the right foot. A - Arrows show skin lesions on the big toe and right foot, $\mathbf{B}$ - photograph showing widespread occurrence of skin lesions on the right foot

cally neoplastic cells showed diffuse immunoreactivity for CD31 antibody (Fig. 2). Kaposi's sarcoma was diagnosed in the patient presenting with atypical skin lesions. Systemic chemotherapy and radiotherapy were begun for treatment of lower extremity KS.

\section{Discussion}

Varicose veins due to chronic venous insufficiency, also called varicosities, are seen most often in the legs, although they can be found in other parts of the body and may increase in frequency with age. Clinical presentations of varicose veins as a result of venous hypertension are edema, hemorrhage, thrombophlebitis, skin pigmentation, telangiectasia, varicose eczema, white atrophy, lipodermatosclerosis, and venous ulceration. In the total population, the incidence of venous insufficiency and its complications is over $80 \%$ [4]. Physical examination is essential in the diagnosis of varicose veins, and Doppler examinations confirm the diagnosis [5].

Venous disease of the legs can be classified according to the severity, cause, site and specific abnormality using the CEAP classification. Skin pigmentation is included in stage C4 of the CEAP classification. Due to the wide range of skin changes considered within stage C4, two subgroups were designated: 1) $\mathrm{C} 4 \mathrm{a}$, including skin pigmentation of any size and severity, and 2) C4b that includes more severe changes with lipodermatosclerosis or white atrophy. Venous insufficiency provokes skin pigmentation, and its nature and pathogenesis are still debatable [5].

Kaposi's sarcoma most commonly presents as cutaneous lesions and may mimic venous stasis ulcers. Lesions are typically plaques, which can become nodular, infiltrative, exophytic, lymphadenopathic, purplish-ecchymotic, telangiectatic or keloidal in nature. Bilaterally symmetric patches of the lower extremities, which progress to stiff nodules identified by palpation, are often the initial presentation of

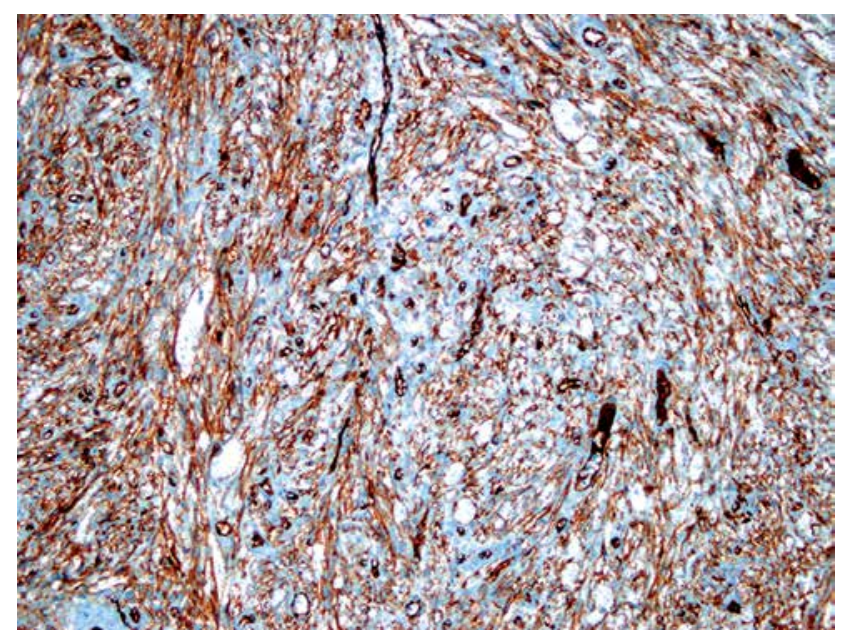

Fig. 2. CD31 immunostaining (200x)

the early stage. More atypical clinical presentations than those with classic variants leading to a diagnostic dilemma of AIDS-associated KS were reviewed as well [1]. This is a case of KS occurring in an old man who presented with skin pigmentation resembling varicose veins on unilateral foot and bewilderingly HIV (-) in serological testing. Sometimes, as in this case, purple, stiff lesions that are atypically present on the legs can be hidden in skin lesions associated with varicosities.

In conclusion, a high index of suspicion and palpation of all lesions are necessary for patients with atypical presentations of varicose-like lesions of lower extremities. If a patient has common wide varicose veins in the lower extremities, all lesions should be evaluated to determine their stiffness or softness with palpation.

\section{Disclosure}

Authors report no conflict of interest. 


\section{References}

1. Johnson EL, Pierpont YN, Donate G, Hiro MH, Mannari RJ, Strickland TJ, Robson MC, Payne WG. Clinical challenge: cutaneous Kaposi's sarcoma of the lower extremity. Int Wound J 2011; 8: 163-168.

2. Antman K, Chang Y. Kaposi's sarcoma. N Engl J Med 2000; 342: 1027-1038.

3. Radu O, Pantanowitz L. Kaposi's sarcoma. Arch Pathol Lab Med 2013; 137: 289-294.
4. London NJ, Nash R. ABC of arterial and venous disease. Varicose veins. BMJ 2000; 320: 1391-1394.

5. Caggiati A, Rosi C, Franceschini M, Innocenzi D. The nature of skin pigmentations in chronic venous insufficiency: a preliminary report. Eur J Vasc Endovasc Surg 2008; 35: 111-118. 